\title{
Review of Research on EFL Flipped Teaching
}

\author{
Fangmin Pu \\ School of Foreign Languages \\ Wuhan Textile University \\ Wuhan, China
}

\begin{abstract}
This paper has reviewed the previous studies on EFL flipped teaching and found the following characteristics. First, most studies have confirmed the effectiveness of the use of the flipped classroom approach in EFL teaching. They have also proved that this approach can bring a lot of benefits to EFL teaching and learning such as enhancing EFL learners' English proficiency and promoting their autonomy, motivation, learning attitudes and engagement in the learning process. And most participants in those studies showed positive perceptions of EFL flipped teaching. Second, in recent years, an increasing number of empirical studies on EFL flipped teaching have emerged and contributed a lot to the body of flipped studies. Moreover, most of those studies have employed both quantitative and qualitative approaches to examine EFL flipped teaching. However, there are still a lot more aspects of EFL flipped teaching that need to be investigated. This paper has also offered some suggestions on the future research in this field.
\end{abstract}

Keywords-EFL flipped teaching; flipped classroom approach; EFL learners; empirical studies

\section{INTRODUCTION}

The new century is witnessing numerous pedagogical innovations, among which the flipped classroom has been arousing public attention. An increasing number of studies have been conducted to explore EFL flipped teaching. This paper aims to review the relevant studies and offer some suggestions on the future research in this field.

\section{RESEARCH ON THE USE OF THE FLIPPED CLASSROOM APPROACH IN EFL TEACHING}

The flipped classroom, sometimes called reverse or inverted classroom, is a pedagogical model in which what traditionally has been taking place inside the classroom now takes place outside the classroom and vice versa. That is, direct instruction is delivered outside of the classroom-mostly through videos, and in class, students engage in studentcentered activities such as games, group discussions, case studies, experiments or doing their homework facilitated by a teacher or an instructor. (Herreid \& Schiller, 2013; Francl, 2014). The flipped classroom approach has many advantages such as allowing the students to adjust their own learning pace, making class time more efficient, increasing opportunities for peer interaction and interaction between the teacher and

This paper is sponsored by WTU Teaching Research Project: The Research on the Use of the Flipped Classroom Approach in College English Vocabulary Teaching. Project number: 2017JY053 students and improving students' academic performance (Fulton, 2012; Davies, Dean and Ball, 2013). Owing to these advantages, the flipped classroom approach has been implemented in many fields of education including EFL teaching. So far, many studies on EFL flipped teaching have emerged and they mainly fall into two major categories: theoretical research and empirical research which contains three subcategories.

\section{A. Theoretical Research on EFL Flipped Teaching}

The implementation of the flipped classroom approach in EFL teaching has drawn a lot of research attention. Some of the relevant studies fall into the category of theoretical analysis, and mainly describe the feasibility of flipping the EFL classroom and how to flip the EFL classroom.

Lu (2014) probed the feasibility of the use of microlessonbased flipped classroom model in college English teaching on the basis of analysis of the characteristics of microlessons and the flipped classroom approach and the feature of college English teachers and college students as well as the current college English teaching environment in China. Correa (2015) described what a flipped foreign language classroom was, discussed some of the most common concerns about flipping the foreign language classroom and suggested possible solutions. Mehring (2016) advocated that flipped teaching could be used in EFL classrooms and it might help to create a communicative, student-centered learning environment in the EFL classroom. He also proposed some useful tools to support EFL flipped teaching and learning. Suo and Hou (2017) expounded how to employ the motivational strategies in the EFL flipped classroom to enhance students' motivation to learn English autonomously and bring the effectiveness of the flipped classroom approach into full play.

\section{B. Empirical Research on EFL Flipped Teaching}

In recent years, many researchers have conducted empirical studies to investigate diverse aspects of EFL flipped teaching. Those studies are chiefly concerned with the use of the flipped classroom approach in EFL listening, speaking, reading, writing and grammar instruction as well as other aspects of EFL teaching.

1) The use of the flipped classroom approach in EFL listening, speaking, reading and writing instruction

Some studies have been conducted to examine the effectiveness of the implementation of the flipped classroom 
approach in EFL listening, speaking, reading and writing instruction. Most of them have proved that the flipped classroom approach can improve EFL learners' listening, speaking, reading and writing level and foster their engagement in the learning process, and that most EFL students hold positive attitudes towards flipped teaching and learning.

On listening instruction, Ahmad's empirical study (2016) employed a one-group pre-posttest design to investigate the effect of the flipped classroom approach on Egyptian EFL students' listening comprehension and found that this approach improved EFL students' listening comprehension significantly.

Concerning speaking instruction, $\mathrm{Wu}$, Hsieh and Yang (2017) used pre-and-post-tests, a survey, semi-structured interviews, and in-class observations by the instructors to examine the impact of an online learning community in a flipped classroom on EFL learners' oral proficiency and students' perceptions of flipped teaching. Their study indicated that the online learning community in a flipped classroom not only facilitated meaningful and positive collaboration but also significantly improved the EFL participants' oral proficiency and their engagement in class activities.

With regard to reading instruction, Huang and Hong (2016) employed pre-and-post-tests, observations and interviews to probe the effects of the flipped English classroom approach on high school students' information and communication technology and English reading comprehension in Taiwan. Their empirical study found that the flipped classroom approach improved students' information and communication technology and English reading comprehension significantly. He (2016) constructed a top-down task-flipped teaching model in English reading classes in a Chinese college and used preand-post-tests, reflective reports and interviews to examine the model. The results showed that, compared with the traditional teaching models, the new model could not only improve the students' English proficiency, but also promote their autonomy, engagement and peer cooperation in the learning process.

In terms of writing instruction, $\mathrm{Yu}$ and Wang (2016) employed a satisfaction scale, a Business English Writing test and a semi-structured interview to investigate the effectiveness of the flipped model in business English writing course. Their study concluded that in the flipped business English writing classroom, EFL students acquired better academic achievements than in the traditional one, and the flipped classroom was more satisfactory than the traditional one. Norazmi, Dwee, Suzilla and Nurzarina (2017) used a questionnaire to examine EFL students' engagement in English for Specific Purposes (ESP) writing in a flipped classroom. Their findings indicated that the flipped classroom approach motivated students to engage in the writing process more actively and effectively, and the students in general held a positive attitude towards the flipped teaching.

2) The use of the flipped classroom approach in EFL grammar teaching

Al-Harbi and Alshumaimeri's empirical study (2016) investigated the effectiveness of EFL grammar flipped teaching and concluded that the flipped classroom approach played a positive but not significant role in enhancing the students' grammar performances and EFL students' attitudes towards the flipped classroom approach were positive.

3) Empirical research on other aspects of EFL flipped teaching

Many empirical studies have also probed the effectiveness of EFL content-based flipped teaching, students' perceptions of the flipped classroom, the effects of the flipped classroom approach on EFL students' academic performance, autonomy, motivation, learning attitudes and engagement in the learning process, the influence of individual characteristics on learning outcomes in an EFL flipped classroom and other aspects.

Regarding the effectiveness of EFL content-based flipped teaching, Sung's study (2015) investigated a flipped English content-based class where 12 EFL college students were enrolled and completed all the course requirements in an elective course, English Curriculum and Evaluation, and the findings showed that EFL students perceived flipped learning positively. Sun's qualitative study (2017) explored EFL learners' perceptions of the content-based flipped classroom approach. It revealed that in general EFL students had a positive attitude towards this approach and they showed improvement in communicative skills, confidence and content knowledge.

As regards students' perceptions of the flipped classroom, Kang (2015) examined the effectiveness and the students' perceptions of flipped classrooms, and found that the EFL students in the flipped classroom made statistically significant progress in vocabulary and grammar knowledge and they were satisfied with the flipped classroom approach. Zhai, Gu, Liu, Liang and Tsai (2017) constructed and evaluated a students' satisfaction model for the EFL flipped classroom based on the experiential learning theory, and found that prior learning experience and personalized learning climate were both important antecedents to predict students' perceptions of the flipped classroom, and EFL learners' prior learning experience was a far more significant predictor of their satisfaction of the flipped classroom than personalized learning climate. Yang (2017) investigated the implementation of the flipped classroom approach in the English Language subject in secondary classrooms in Hong Kong and concluded that students in general perceived the flipped classroom positively. Zainuddin (2017) explored the first-year college students' learning and experiences in an EFL flipped classroom and found that The flipped teaching boosted students' enthusiasm for learning and enhanced peer interaction, and that most students held a positive attitude towards the flipped teaching.

With regard to the effects of the flipped classroom approach on EFL students' academic performance, autonomy, motivation, learning attitudes and engagement in the learning process, etc., Hung (2015) examined the impacts of the flipped classroom on EFL learners' academic performance, learning attitudes, and participation levels. The results indicated that the structured and semi-structured flipped classrooms were more effective instructional designs than the non-flipped classroom, and both the structured and semi-structured flipped classroom approaches improved the students' academic performance, learning attitudes and engagement. Alsowat's study (2016) discovered the EFL Flipped Classroom Teaching Model had a 
significant effect on graduate students' English higher-order thinking skills, engagement and satisfaction. Zainuddin and Perera's empirical study (2017) showed that EFL students in the flipped classroom were more competent in handling online tasks and activities, and were able to control their learning outcomes. The study also found that the flipped teaching fostered better peer interaction and enhanced EFL learners' autonomy and intrinsic motivation. Hsieh, Wu and Marek (2017) conducted an empirical study to explore what benefits EFL learners could get from the flipped classroom approach. The findings of the study revealed that EFL learners learned English idioms more effectively in the flipped classroom than in the conventional one. In other words, the flipped teaching contributed to significantly better learning outcomes than the conventional teaching. The study also found that the flipped classroom approach boosted EFL learners' motivation to learn and use English idioms and engaged them in the learning process, and that most of the EFL participants were satisfied with the flipped teaching. Doman and Webb (2017) conducted a study to show that EFL students in the flipped classroom had more positive learning attitudes than those in the non-flipped classroom. Hung's research (2017) revealed that EFL students in the flipped classroom outperformed those in the non-flipped classroom in their academic achievement significantly. In other words, the flipped classroom approach had a positive effect on EFL learners' academic performance. The study also suggested that the flipped classroom approach had a positive effect on students' learning attitudes.

With respect to the influence of individual characteristics such as learner motivation, self-efficacy and epistemology beliefs on learning outcomes in an EFL flipped classroom, Chuang, Weng and Chen (2016) conducted an empirical study to find that EFL learners with a high level of motivation in instrumentality benefited most from the flipped classroom. Beliefs also seemed to contribute to better learning outcomes in the flipped classroom, because EFL learners with high beliefs showed more progress in the post-test.

\section{REFLECTION ON PREVIOUS RESEARCH ON EFL FLIPPED TEACHING}

Previous studies on EFL flipped teaching have made a great contribution to the field of EFL education. They mainly demonstrate the following characteristics.

First, most studies have confirmed the effectiveness of the use of the flipped classroom approach in EFL teaching. They have also proved that this approach can bring a lot of benefits to EFL teaching and learning such as enhancing EFL learners' English proficiency and promoting their autonomy, motivation, learning attitudes and engagement in the learning process. And most participants in those studies showed positive perceptions of EFL flipped teaching. Those findings can give EFL teachers a deep insight into how to flip EFL classrooms and motivate them to apply the flipped classroom approach to their teaching.

Second, in recent years, an increasing number of empirical studies on EFL flipped teaching have emerged and contributed a lot to the body of flipped studies. Moreover, most of those studies have employed both quantitative and qualitative approaches to investigate EFL flipped teaching. For instance,
Wu, Hsieh and Yang (2017), Huang and Hong (2016), He (2016), Yu and Wang (2016), Al-Harbi and Alshumaimeri (2016), Kang (2015), Yang (2017), Zainuddin (2017), Hung (2015), Zainuddin and Perera (2017), Hsieh, Wu and Marek (2017) and Hung (2017) have conducted such studies which have used mixed research methods.

On the whole, many studies, especially empirical studies have delved into diverse aspects of EFL flipped teaching. However, there are still a lot more aspects in this field that need to be investigated. For example, future research can probe the impact of the flipped classroom approach on EFL learners' translation competence and critical thinking and the effectiveness of EFL flipped vocabulary instruction, etc.

\section{CONCLUSION}

Many studies have described how to flip EFL classrooms and investigated the effectiveness of EFL flipped teaching, which has been proved to enhance EFL learners' English proficiency, promote their autonomy, motivation, learning attitudes and engagement in the learning process, foster peer interaction and improve learners' communicative skills. It's also confirmed that most participants hold a positive attitude towards EFL flipped teaching. These benefits of the EFL flipped classroom approach previous studies have shown will motivate more and more teachers to implement this new approach in their teaching, and more and more researchers will explore new aspects of EFL flipped teaching such as the impact of the flipped classroom approach on EFL learners' translation competence and critical thinking and the effectiveness of EFL flipped vocabulary instruction.

\section{REFERENCES}

[1] C. F. Herried and N.A. Schiller, "Case studies and the flipped classroom," Journal of College Science Teaching, Vol.42, No.5, pp.6266, 2013.

[2] T. J. Francl, "Is flipped learning appropriate," Journal of Research in Innovative Teaching, Vol.71, pp.119-128, 2014.

[3] K. Fulton, "Upside down \& inside out: flip your classroom to improve student learning," Learning \& Leading with Technology, Vol.39, No.8, pp.12-17, 2012.

[4] R. Davies, D. Dean, and N. Ball, "Flipping the classroom \& instructional technology integration in a college-level information systems spreadsheet course," Educational Technology Research \& Development, Vol.61, No.4, pp.563-580, 2013

[5] Haiyan $\mathrm{Lu}$, "The feasibility analysis of the application of microlessonbased flipped classroom model in college English teaching," CAFLE, Vol. 158, pp.33-36, 2014.

[6] Maite Correa, "Flipping the foreign language classroom and critical pedagogies: a (new) old trend," Higher Education for the Future, Vol.2, No.2, pp.114-125, 2015.

[7] Jeff Mehring, "Present research on the flipped classroom and potential tools for the EFL classroom," Computers in the Schools, Vol.33, No.1, pp.1-10, 2016.

[8] Jia Suo and Xiuying Hou, "A study on the motivational strategies in college English flipped classroom,” English Language Teaching, Vol. 10, No. 5, pp. 62-67, 2017.

[9] Samah Zakareya Ahmad, "The flipped classroom model to develop Egyptian EFL students' listening comprehension," English Language Teaching, Vol. 9, No. 9, pp. 166-178, 2016.

[10] W.-C. V. Wu, J. S. Chen Hsieh, and J. C. Yang, "Creating an online learning community in a flipped classroom to enhance EFL learners' 
oral proficiency," Educational Technology \& Society, Vol. 20, No.2, pp.142-157, 2017.

[11] Yu-Ning Huang and Zuway-R Hong, "The effects of a flipped English classroom intervention on students' information and communication technology and English reading comprehension," Education Tech Research Dev, Vol. 64, pp.175-193, 2016.

[12] Xueqin He, "An empirical study on the top-down task-based English reading teaching in a flipped classroom," Foreign Language World, Vol.4, 2016.

[13] D. Norazmi, C. Y. Dwee, J. Suzilla, and A. S. Nurzarina, "Exploring student engagement in writing using the flipped classroom approach," Social Sciences \& Humanities, Vol.25, No.2, pp. 663-674, 2017.

[14] Zhonggen $\mathrm{Yu}$ and Guifang Wang, "Academic achievements and satisfaction of the clicker-aided flipped business English writing class," Educational Technology \& Society, Vol.19, No.2, pp.298-312, 2016.

[15] Sarah S. Al-Harbi and Yousif A. Alshumaimeri, "The flipped classroom impact in grammar class on EFL Saudi secondary school students' performances and attitudes," English Language Teaching, Vol. 9, No. 10, pp. 60-80, 2016.

[16] Kiwan Sung, "A case study on a flipped classroom in an EFL content course," Multimedia-Assisted Language Learning, Vol. 18, Issue 2, pp.159-187, 2015.

[17] Yu-Chih Sun, "Flipping every student? A case study of content-based flipped language classrooms," E-Learning and Digital Media, Vol.14, pp.20-37, 2017.

[18] Namhee Kang, "The comparison between regular and flipped classrooms for EFL Korean adult learners," Multimedia-Assisted Language Learning, Vol.18, No. 3, pp.41-72, 2015.

[19] Xuesong Zhai, Jibao Gu, Hefu Liu, Jyh-Chong Liang, and Chin-Chung Tsai, "An experiential learning perspective on students' satisfaction model in a flipped classroom context," Educational Technology \& Society, Vol. 20, No.1, pp.198-210, 2017.

[20] Chi Cheung Ruby Yang, "An investigation of the use of the "flipped classroom' pedagogy in secondary English language classrooms," Journal of Information Technology Education: Innovations in Practice, Vol.16, pp.1-20, 2017.

[21] Zamzami Zainuddin, "First-year college students' experiences in the EFL flipped classroom: a case study in Indonesia," International Journal of Instruction, Vol.10, No.1, pp.133-150, 2017.

[22] Hsiu-Ting Hung, "Flipping the classroom for English language learners to foster active learning," Computer Assisted Language Learning, Vol. 28, No. 1, pp.81-96, 2015.

[23] Hamad Alsowat, "An EFL flipped classroom teaching model: effects on English language higher-order thinking skills, student engagement and satisfaction," Journal of Education and Practice, Vol.7, No.9, pp.108$121,2016$.

[24] Zamzami Zainuddin and Corinne Jacqueline Perera, "Exploring students' competence, autonomy and relatedness in the flipped classroom pedagogical model," Journal of Further and Higher Education, Vol. 5, pp.1-12, 2017.

[25] Jun Scott Chen Hsieh, Wen-Chi Vivian Wu, and Michael W. Marek, "Using the flipped classroom to enhance EFL learning," Computer Assisted Language Learning, Vol. 30, pp.1-21, 2017.

[26] Evelyn Doman and Marie Webb, "The flipped experience for Chinese university students studying English as a foreign language", TESOL Journal Vol.8, No.1, pp.102-141, 2017.

[27] Hsiu-Ting Hung, "Design-based research: redesign of an English language course using a flipped classroom approach,” TESOL Quarterly, Vol. 51, No.1, pp.180-192, 2017.

[28] Hsueh-Hua Chuang, Chih-Yuan Weng, and Ching-Huei Chen, "Which students benefit most from a flipped classroom approach to language learning?" British Journal of Educational Technology, Vol. 00, No. 00, pp.1-13, 2016. doi:10.1111/bjet.12530. Retrieved from http://onlinelibrary.wiley.com/doi/10.1111/bjet.12530/full 